\title{
Managing managers: an early twentieth century service industry information system
}

\author{
Dr Alistair Mutch
}

Senior Lecturer, The Nottingham Trent University

Department of Finance and Business Information Systems, Burton Street, Nottingham, NG1 4BU

Email:_ alistair.mutch@ntu.ac.uk

\section{Abstract}

This article examines the construction and operation of a service industry information system in the early years of the twentieth century. It sets the operations of the Birmingham, UK, company of Mitchells and Butlers in the context of the brewing industry and the operation of public houses. The surviving records are used to construct a picture of a complex and sophisticated information system which not only used accounting records to control managers, but also used the same managers as sources of information about the broader context. The apparent success of this system is set against the reluctance of other brewers to adopt it. This is seen in part to relate to the very complexity of the information system created, but also to the broader perceptions of brewers about the nature and status of their trade.

Key words: information systems history; brewing; retailing; management information systems; management history.

\section{Introduction}


This article looks at the inter-relationship between the growth of managerial systems and the development of information systems. Yates (1989) has pointed to the importance of communications technologies in the application of 'systematic management' in the United States. The prime focus of this work was on manufacturing industries. Levenstein's (1998) work extends the focus to continuous process organisations, using the case of Dow. However, there were service industries which were starting to gain significant regional or national scope towards the end of the nineteenth century, organisations which faced the problem of controlling multiple, geographically distributed outlets. One such industry was brewing in late nineteenth and early twentieth century England, and this is the focus of this article. In particular, the article looks at the way information systems were vital in the constitution and creation of a group of managers - and the ways in which they may have prevented the generalisation of such a group from innovators to the broader industry. In doing this, the article aims to shed light on the way in which managers, as well as shop floor workers, came to be controlled and constituted, in part, through information. It also seeks to develop explanations which go beyond the drive and dynamism of individual innovators, using Galbraith’s notion of ‘centre of gravity’ (Galbraith, 1991).

The article begins by outlining the nature of the English public house and the various ways in which it could be occupied. It then looks briefly at the characteristics of those who ran public houses with a view to outlining the distinctive features of house managers as opposed to tenants. This allows us to look at some of the requirements of a managerial system before looking at actual practice in two companies. This examination, which is conditioned by the nature of the surviving evidence, contrasts the different approaches of Peter Walker of Warrington and Mitchells and Butlers $(M \& B)$ of Birmingham. The practices of the latter firm are then examined in more 
detail, to show how a complex information system was built. The very complexity of this system, it is argued, was a prime reason why the apparent success of M\&B was not widely imitated. This is set in the context of other, inter-related reasons, with a particular focus on the nature of pub operations and the image of the tenant in the eyes of brewers.

\section{Managers and tenants in nineteenth century English public houses}

This article consciously and deliberately confines its focus to practice in England as social practices in Scotland and Wales introduce different dimensions. The public house and its landlord are a powerful part of English mythology, as are the various terms for the public house - the inn, the tavern, the hostelry. These form part of the traditions of 'Merrie England' and one of the problems of studying them is the powerful dose of nostalgia that is associated with them (Jennings, 1995). For the purpose of this article we need first to understand the situation in the closing years of the nineteenth century. There were two types of outlets which were licensed by the state, through its intermediaries the licensing justices, to sell intoxicating liquor for consumption on the premises (Gourvish and Wilson, 1994). These were the full license and the beerhouse. The first offered a full range of products from beer to spirits, sometimes including food and accommodation, and were run by those often styled 'licensed victuallers' or 'publicans'. The beerhouses were a creation of the early nineteenth century and were only allowed to sell beer. Before 1869 they were subject to only minimal control. They were small outlets in accommodation that was often indistinguishable from the houses, usually of the working poor, that surrounded 
them. The distinctions between the two types of outlet were to blur considerably and eventually disappear, but both served an almost exclusively working class, and often (depending on locality) male, clientele.

There are three models for occupancy of a public house (for a broad, if superficial, historical overview, see Haydon, 1994). One is to own and run the house as an independent business. 'Free houses' are those who can buy their products from any source. From the late nineteenth century onwards, this model began to be replaced by ties, in which publicans were expected to sell the products of one particular brewery. This came with the widespread decline of the publican-brewer, whose brews for sale on the premises were replaced by the products of the brewers such as Whitbread, Bass and Courage who were starting to achieve regional importance (Gourvish and Wilson, 1994). These brewers increasingly looked towards the ownership, rather than just the supply, of public houses, in order to protect the production volumes which made their growing breweries run at peak efficiency. The tie took two forms. In London it took the form of loans with the expectation, more or less enforced, that in return the brewer's products would be stocked. Across the rest of England and Wales the more common model was for the brewery to own the house, which was let at a low rent but with restrictions as to what could be sold. As a minimum this generally meant that only the brewer's beers could be stocked, but this restriction could extend to spirits, mineral waters and cigars. The final model, with which this article is concerned, was for the house to be run by a salaried manager. In this situation the products stocked were exclusively those supplied by the brewer, who took all the profit in return for the payment of a weekly wage. The emergence of managers is often tied to the incorporation as public companies of many of the major brewers in the 1890s. This 
was coupled with the attention given to the topic by many of the witnesses examined by the marathon sessions of the Royal Commission on the Licensing Laws (the Peel Commission) running from 1897 until 1899. This has led Gutzke (1989: 181) to claim that,

As breweries became large-scale and corporate management replaced private control, retailers found their brewer-landlords increasingly impersonal and inflexible, even ruthless in maximising profits. What so strained the loyalty of both publicans and beerhouse keepers to trade defence was the encroachment on their monopoly as distributors of beer by brewers who themselves entered the business of retailing.

The degree of ruthlessness was, it could be argued, more an issue of perception. Again, we are faced by the considerable nostalgia that informs analyses of brewing. This article will argue both that managers emerged earlier than the 1890s and that a number of factors prevented brewers as a whole exhibiting the degree of ruthlessness that Gutzke claims. However, before examining the basis for these claims, it is firstly useful to consider some of the characteristics of the running of a public house and those who performed this activity.

One of our problems in doing this is that we often know more about opposition to the drink trade than about those who made their living in it (Harrison, 1994). Within the trade, as we shall see later, the emphasis has been on brewing and production issues (Gourvish and Wilson, 1994). Within social history, the pub often appears as an important venue for social activity, but the characteristics of the person behind the bar 
are not subject to much scrutiny (White, 1986; Hoggart, 1971; Mass Observation, 1970). The contributors to Crossick's (1977) examination of the lower middle class in nineteenth century Britain, for example, mention publicans only in passing and give no serious consideration to their status. Roberts (1971) account of life in Edwardian Salford indicates the status that attached to even the lowliest beerhouse, although these were clearly at the bottom of a hierarchy which culminated in the Duke of Clarance, run by a,

little dark widow of such refinement that not more than half a dozen of her customers were considered worthy of verbal salute. Others received her nod and the lower breeds a cold state. Seldom seen, she delegated authority to two solemn barmen who allowed no singing, drunkenness or bad language (Roberts 1971: 94).

Her status as widow indicates the common route for women to hold licences. Most licensees were in fact men. In Bradford in 1891 only $12 \%$ of houses were run by single women and the vast majority of these were widows. Over three quarters of houses were occupied by married couples, with the man being accorded the licence (Jennings, 1995: 181-182). This figure is mirrored almost exactly in Nottingham in the same year, where $12.5 \%$ of 312 houses were run by women. ${ }^{1}$ The Nottingham and Bradford figures agree on another dimension, that of age. In Nottingham the average age of licensees was 45.6, in Bradford just under 44. Whilst this tells us nothing about age on entry to the occupation, a much later study indicates that this was around 36 (Hyde, 1974). Being a publican, especially in the smaller beerhouses, 
was a change in occupation, often one undertaken by those in first occupations like the police, the services or sports which by their nature required a shift in mid-life. Nevile (1958) of Whitbread observed that "Many of the less important houses were kept by elderly couples who 'took a pub' when the husband retired after spending most of his working life elsewhere." (157). This might be stretching the point as little, but it does indicate that little or no qualification was required to become a publican. Indeed, Nevile was a pioneer in suggesting in 1911 that training courses in cellar management might be provided.

If we know little about the profile of publicans in general, we know still less about managers. A limited sample of 22 Birmingham managers in 1891, (derived from the surviving records of Mitchells and Butlers, examined below) shows a much younger average age of 36.8 years. Interestingly, of the 5 women who constituted $23 \%$ of the sample, three were in their 20s, contributing to an average age for women of just 33. Only one of these women was single, but it is interesting that the husbands of the rest were all employed in trades which took them outside the public house. These figures can only be suggestive in the absence of more detailed work on the census records (which would, of necessity, be very time consuming), but they do indicate that, in Birmingham at least, managers might have a slightly different profile from that of publicans in general, being more likely to be younger and/or female. One instructive difference between managers and tenants might be suggested by the tenancy and management agreements that the Birmingham company of William Butler submitted to the Royal Commission. The tenancy agreement allowed for a mark to be made, the management contract required a signature. This points to a key difference, the need

\footnotetext{
${ }^{1}$ All figures quoted for Nottingham are based on an analysis of the census enumerators returns for
} 
for at least basic literacy and numeracy to be able to keep house accounts. A Butlers’ manager was to

keep such books of accounts as shall be required and supplied by the employers and he shall enter therein daily an account of all moneys received by him on the day of such entry for or on account of the employers. The manager shall also enter in a book or books to be supplied for that purpose by the employers an account of all goods which shall be supplied to him by the employers for sale (Peel, 1897a, 449)

In a Manchester agreement, the manager agreed that, "I will keep the cash account, books or papers belonging or relating to the business of my said employment, or otherwise, coming under my care, in a proper and business-like manner” (Peel, 1897b, 375).

More might have been expected of managers, but their legal status was tenuous. The issue was not only debated in the Royal Commission, but also formed the basis of numerous court cases until it was decided in 1917 that managers were 'fit and proper' persons to hold licences (Jennings, 1995). One impact of this uncertainty was to give magistrates considerable direction in whether to grant licences to managers, and this shaped brewery practices. Magistrates were often prepared to allow brewers to put in managers on a temporary basis whilst they looked for a new tenant (Peel, 1898a, 32). This was as much as some companies required. Truman \& Buxton, for example, only used managers "in exceptional cases" and had no desire to extend their use further 
(Peel, 1898a, 299). However, in other cases companies wanted to use managers on a more extensive basis, but had to disguise the nature of the employment contract. One witness to the Royal Commission alleged that " 90 per cent of the licenses that are obtained before the licensing magistrates in Manchester are bogus. ... I have had to do the same thing myself when I was manager for a brewery” (Peel, 1897b, 441). A tenancy agreement might be presented to the court, but this was never enforced, being replaced by a contract to manage the outlet week by week. The chair of Manchester magistrates recognised the problem, arguing that after asking the applicant for confirmation of a bona fide tenancy and seeing a signed agreement, they "have felt themselves powerless to do more than has already been done” (Peel, 1897b, 460). What is important for us here is that such practices make it difficult to establish the extent of the practice of employing managers. It is clear from the evidence supplied to the commission that managers were particularly prevalent in Birmingham and Liverpool. The clerk to Birmingham magistrates estimated that of 1467 houses in the city, 414 were managed, whilst the Chief Constable of Liverpool indicated that 1057 of the city’s 2078 houses were managed (Peel, 1897a, 233; Peel, 1898a, 4). One of the problems in establishing a clear pattern across the country is the lack of data. When the Commission asked magistrates to indicate whether managers were allowed in their areas, they were forced to conclude that, “This question seems in a good many cases not to have been fully understood, and consequently it is somewhat difficult to summarize the results.” (Peel, 1898b, 40).

The evidence does indicate, however, that the depth of commitment to the systematic use of managers varied. The Manchester witness cited above outlined a situation where managers were not in the permanent employment of the brewers, but were used 
to meet specific circumstances. Thus, "If there is a bad house to be worked up we can generally put our hands on him and ask him to work it up, and after he has worked it up he gets a small consideration and has to go out, because we have got a tenant for it” (Peel, 1897b, 442). However, there were companies who were far more committed to the systematic employment of managers, and it is to these that we turn our attention next. Peter Walker of Warrington had pubs in Liverpool and gave evidence to the Peel Commission; Mitchells and Butler was the dominant Birmingham brewery and was used to support the Birmingham evidence. They both used managers extensively. However, some words of warning are in order about the nature of the records that survive for both organisations. The evidence from Walkers is limited to published material. In the case of M\&B there is a good run of directors' minute books which we can back up with at least some of the prime documents. With this caveat in mind, we turn to look at practice in Walkers first, before looking at the M\&B case in more detail.

Peter Walker started brewing in Warrington in 1846 (Barnard, 1889: 95). The company began the employment of managers in its houses in the late 1870s and claimed that they were, "generally credited with being the originators of the system" [of house managers] (Peel, 1898a: 391). Indeed, the company used five pages of its jubilee celebration book to elaborate on and defend this system (Walkers, 1896). This involved the institution of systems for recording sales by house, backed up by a strict code of conduct for managers, a copy of which was lodged with the Commission. This was backed up by " a very strict system of control, that is to say, by the appointment of outdoor inspectors, or outdoor managers. We have a thoroughly organised staff of managers, whose duty it is to go into the houses at all times of the 
day, and all times of the night” (Peel, 1989a: 393). This attention to control was the chief rhetorical device used to persuade readers that the 'managerial system' was one to be admired and accepted, rather than reviled as an attack on traditional English practices. The claim was made that, "The Managerial System, in fact, offers the prospect of order evolved from chaos” (Walkers, 1896, p. 56). This was set in the context of the "natural evolution of our commercial system" which "has subjugated the instinct and the opportunity for petty personal greed, to the interests of the public at large” (Walkers, 1896, p. 56). Unfortunately, none of the records which might be taken to have backed up Walker's system have survived, but much more can be gleaned from the M\&B archives.

M\&B was formed in 1898 from the merger of two well established Birmingham firms, William Butler and Henry Mitchell. Both were brewers, but whilst Mitchells had a large brewery at Cape Hill which was the major focus of their activities, Butlers was more of a retailing company, which had, according to Nevile(1958) expanded into brewing to serve a growing number of outlets. In common with a number of Birmingham brewers, Mitchells did manage some of its outlets, but this was only, in 1888, a quarter of its outlets (Companies House,1888). It would seem that Butlers were much more committed to the management of houses as a systematic practice, something reflected in the fact that Butler was immediately put in charge of the managed houses, and under this influence the company began to put in place an elaborate system for controlling its managed outlets (M\&B, 1898). It is to what we can glean of this system that we turn next. 


\section{Managing managers: creating an information system.}

In distinction to the practice in many other brewers (Neville 1958; Mason, 1982), M\&B's reporting was carried out by their own staff and much more thoroughly. Just how thoroughly is a matter of some conjecture, for the minutes that survive can only indicate a small part of the activity that might have been carried on. We do, however, have minute books of the managing directors’ meetings which are sketchy from 1898 but comprehensive from 1903. It is in this year that we start to get references to a ‘Managed House Report’ (M\&B 1903). This was compiled by A. W. Edge, the 'superintendent of managed houses'. Just what was in this report is not clear, but a note in 1904 that the participants, "Went through Houses down in takings \& profits, a large quantity unsatisfactory.” (M\&B, 1904a)) gives an indication. Three weeks later the minutes record that they went through not only 'Mr Edge's report', but also a "stocks and takings which were down in previous weeks report." (M\&B, 1904b). Throughout the year these two reports seem to be considered (or at least their consideration is recorded) on a weekly basis. In the following year, these reports were elaborated still further. In addition to Edge’s summary report, the Board were now considering a ‘bad stocks’ report and a ‘takings down’ report (M\&B, 1905a). By the end of the year specific action points begin to be recorded - Mr Astbury was, for example, “To see if Inspectors and Stocktakers make a practice of initialling the takings sheet when visiting houses” (M\&B 1905b).

We can get some indication of the likely contents of Edge's report from the substructure of records that supported this evolving report process. It appears that an account was kept for each house recording the details of stocks and moneys taken, 
although none of these detailed ledgers has survived. What has survived is a cash book for 1913 which summarised takings for managed houses (M\&B, 1913). The comparisons this gives are instructive. In one part of the ledger, identical houses are compared with the same group in the previous year. For each week, the total takings were compared to the corresponding week in the previous year and an average take per house for each period contrasted. Then the average and total for all houses for the current week is recorded, followed by a breakdown of sales showing sales of bottled goods and mineral waters. Wages and purchases were recorded and a calculation made of the percentage that both wages and costs represented of sales - measures that are still widely used in contemporary liquor retailing. What this indicates is two things. One is that the Board were interested in monitoring, in quite a detailed level, the progress of their managed house week by week. They used the additional information that they got from managed houses as opposed to tenancies (where they could only know rental income on a periodic, usually quarterly basis, and stock ordered and paid for) to look for trends and problems. They then used this to intervene in a surprisingly detailed and personal fashion. For example, in 1909 the minutes record:

White House, Congreve St - trading - Mr C Mitchell reported that Mr W. W. Butler, Mr Edge and himself had spent last Wednesday afternoon at the House and had particularly investigated the staff list and other expenditure and had concluded that the Staff could not be reduced and that the only way to make the House pay is to increase the turnover (M\&B, 1909). 
The second thing is the extent and complexity of the records needed to supply the data which prompted such activities. What survives in addition to the cash summaries is a series of house ledgers. These pre-printed forms are bound in large ledgers which cover some 300 houses and whose numbering suggests they began around 1907. (The earliest surviving example dates from 1935). This 'house database' contains, on one sheet, details of the house - its purchase date, its rental if appropriate, the record of tenants or the managed house folio number - and on a facing sheet, seven years data on average weekly takings, gross quarterly profit percentage, number of barrels sold and a number of other items (M\&B, 1935). All of this data is entered by hand, although the pro-formas themselves are printed. This gives us some indication of the scale of labour required, as does a 1929 picture of part of the offices at Cape Hill, showing serried ranks of male clerks standing at high desks, all with their large ledgers (Mitchells \& Butlers, 1929). Unfortunately, we have no accounts of the operation of this office, but the labour requirement must have been considerable and we will return to this later. However, there were other ways in which M\&B used its managers as a source of information and other types of information which it used to control them.

The minutes suggest that as well as using accounting based controls, the company was evolving a ‘human resources’ system. In 1906 Edge was asked to maintain a register of managers considered suitable for promotion (M\&B, 1906a). This interest extended to reports being commissioned on the wages and training of barmen, although there is nothing to suggest that this covered promotion to management (M\&B 1906c, 1906d). Edge also kept a list of managers dismissed (M\&B, 1908a), although the Board wanted to know what use he made of it. There are also references 
to the updating of procedures in an Instruction Book (M\&B 1906b)) and the enforcement of these by a staff of inspectors. We learn, for example, that these were to be paid 10s 6d for each round of night visits they made (M\&B 1908b). However, information flows were not to be all one way. In 1905, for example, a report was to be prepared about the supply of mineral waters to houses which was to include "the Manager's opinions of the quality” of the supply (M\&B, 1905c). Apparently this might not have been all it should be, for a month later a list was to be supplied to inspectors of managers' complaints about mineral waters "with instructions to see the managers and minutely investigate complaints” (M\&B, 1905d). This gathering of information was taken further in 1907 with a note resolving, “Newspapers of districts in which we hold licensed houses. Managers and tenants to be requested to report to us on matters affecting the trade” (M\&B, 1907). This sort of general information gathering was complemented by an expectation that individual managers would prepare reports on matters affecting their own house. When considering an extension to the Crown in Coventry, the board recorded, "Manager written to make a report on the particular days and times when he is most busy and when accommodation is insufficient for the trade" (M\&B, 1906c). All this records a picture of active information gathering and dissemination that contrasts sharply with the patterns which seem to have been prevalent in other breweries.

Before examining the fate of this complex system in the years following the First World War, it is interesting to speculate briefly on why M\&B should have evolved such a system. One indicator is the comment in his 1907 obituary that, "it was always felt that Mr William Butler was more a retailer - although he was a brewer - than any other member of the trade” (Birmingham Daily Mail, 1907). This suggests an 
orientation on public houses that was more than viewing them as a simple shop window. This orientation is reflected in the statement to shareholders in 1921 that the company used management as a means of ensuring control over quality and the improvement of premises (Hawkins, 1978). These objectives would suggest that information was required to satisfy them, but this does not explain why the company should construct such elaborate systems. Perhaps a further clue is in the early setting up of a 'statistical department', suggesting that the company was influenced by the growing influence of the statistical movement (M\&B, 1898). Mackenzie (1981) has pointed to the limited commercial impact of this movement, but interestingly points to work done by Guinness from 1899. There is a tantalising glimpse here of another brewer being interested in this area, but our sources allow us no further detail. What we can point to is a brewing company with an unusual interest in retailing and a willingness to experiment and develop information systems to help it further this interest. However, given the continuing financial success of $M \& B$, which was widely regarded as a particularly well run operation (Nevile, 1958), one might ask why its example was not more widely copied. For it remained the case that, whilst Mitchells and Butlers continued to place houses under management, with $86 \%$ of their 873 houses so operated by 1949 , only $17 \%$ of brewers houses were under management that year (Gourvish and Wilson, 1994: 436).

\section{Fossilisation and failure}

Whilst we could point to a number of reasons for the failure of other brewers to adopt the successful systems operated by M\&B (Mutch, 1999), for the purpose of this 
article we will focus on information systems. Here, we could point to a number of factors. One is the 'fossilisation' of systems at M\&B itself. This might have prevented the innovations being copied elsewhere, given the complexity and expense of these systems. Once again, the comments about the limitations of the sources have to be repeated. The evidence for the fossilisation of M\&B's systems is somewhat conjectural, but it fits with what we know about practice elsewhere in Britain. Campbell-Kelly (1994) has written illuminatingly about office practices in the Railway Clearing Houses. This enormous operation, employing 2,503 clerks in 1913 to deal with 17.6 million transactions, was entirely dependent on manual labour until 1911 and even then any form of mechanisation was slow. This lack of flexibility that the use of hand-written ledgers meant, as opposed to the use of cards and filing systems being adopted in the USA (Yates, 1989), that any extraction of information was a slow and laborious process. We can use the shareholders returns for $M \& B$ which had to be filed with Companies House as an index of the process there. The first time this is typed is in 1920, when the names and addresses of some 4,997 shareholders are typed on to pre-printed forms - although their occupations and holdings are still entered by hand (Companies House, 1920). The hand-written nature of the house records on the eve of the Second World War, as noted above, would seem to be further evidence of the failure to update record keeping methods. This would set the scene for a new Chief Executive, appointed from outside the company, to conclude in 1956 that too many people were employed in relation to business volumes. It seems, too, that the company had lost its retailing focus: Hawkins notes that, despite, "considerable expertise in the management of tied trade ... there was little co-ordination between the marketing function on the one had and the production department on the other." (Hawkins, 1978: 161,162) 
We might suggest, then, that the very sophistication and complexity of the information systems created were a barrier to their adoption by others in the industry. We have already noted the use of external agencies, such as accountants and auditors, to complete even basic costing exercises. This, too, could be the practice in using managers. When Shipstones, for example, wanted what appears to have been a temporary manager to run the Leopard Inn, they used a local firm of Auctioneers and Valuers to set up the contract, a contract which was far less complex that the Butler's agreement cited above (Shipstones, 1909). With the rudimentary offices run by such companies, it is perhaps hardly surprising that many chose to remain with tenancies for the simplicity which they offered. The managing director of Newcastle Breweries acknowledged of managed houses that, "The control is more efficient. But you ask me which I prefer. I think the easiest to manage is the tenancy system” (Peel, 1898a, 369). This might also suit the predilection of many directors for the detailed personal control of their estate.

It also fitted the perceptions of directors about what business they were in. We might usefully view this through the lens of Galbraith's (1991) notion of 'centre of gravity'. The centre of gravity relates to where in the supply chain of a particular industry that a company started its operations. A company closer to the production end of the chain would, argued Galbraith, emerge with a different set of perspectives to one which emerged within the same industry, but closer to distribution. They would have learned particular ways of operating which would be persistent and pervasive. In the late nineteenth and early twentieth century English brewing industry, Peter Walker and Mitchells and Butlers both stand out as having their origins in a retailing orientation. 
This is strongest for M\&B, who we have seen moving into brewing to secure supplies for the growing network of houses. Andrew Walker, the prime mover in the creation of Peter Walker and Son, ran a wine and spirit business in Liverpool with "pub owning interests”.(Moynihan, 1986: 9) before moving into brewing in partnership with his father in 1846 . These patterns were in stark contrast to the majority of the industry, which was firmly production led, and in which there was a strong identity with the 'landed interest' (Gutzke, 1984). This difference in the centre of gravity suggests why certain firms were particularly innovative, but also indicates the reasons why their innovations failed to spread. Without significant changes in the centre of gravity of the majority of companies in the industry, there was no incentive to adopt what appeared to be complex and costly systems of control. The industry would continue to rely on more traditional means of control in its distribution network until well into the 1950s.

\section{Conclusion}

Gourvish and Wilson (1994: 397), in their comprehensive history of British brewing point out that,

The precise nature of their managerial hierarchies, the directors' areas of responsibility, the functions and status of the salaried staffs, the reporting lines and the control of managers and agents in the breweries' national distribution networks, the presence (or absence) of accounting and financial expertise in decision-making and control systems - all remain a mystery 
It is hoped that this article has shed a little light on this topic, but this is not to endorse their recommendation that we follow the example of Beninger. At the heart of Beninger's project is an explicit programme of the reduction of human affairs to matters of information. His contention is that, "It is to these fundamental informational concepts, I believe, that we social scientists may hope to reduce our proliferating but still largely unsystematic knowledge of social structure and process." (Beninger, 1986: 436). In our wish to illuminate the important place of information in human affairs before the coming of the computer, we need to avoid the alternative trap of seeing everything as information. In this, we join with Bowker when he points out that "The global statement that everything is information is not a preordained fact about the world, it becomes a fact as and when we make it so”(Bowker, 1994: 245).

It is recognised that the evidence itself is fragmentary and so any interpretation must be fragile and provisional. Clearly, it would be useful to know more about why M\&B in particular should choose to develop such an elaborate and sophisticated system, just as it would be valuable to know more about its operation and subsequent failure to develop. However, there is enough evidence to point to the development of a service industry information system in the late nineteenth and early twentieth century. This system was centrally concerned with 'managing managers'. However, it went beyond just being a control system and had aspects of information and knowledge sharing. Rudimentary as these might have been, their existence is a salutary corrective to the over-identification of both knowledge and information with information technology.

\section{Acknowledgements}


My thanks to staff at the Bass Museum, Burton on Trent; Warrington Central Library; Companies House, London; and Nottinghamshire Archives, Nottingham. My thanks in particular to Liz Press at the Bass Museum, whose friendly help started my exploration in the Mitchells and Butlers papers.

\section{References}

Barnard, A. (1889), The noted breweries of Great Britain and Ireland in three volumes. 2, Sir Joseph Causton \& Sons, London.

Beninger, J. R . (1986), The control revolution. technological and economic origins of the information society, Harvard University Press, Cambridge, Mass.

Bowker, G. (1994), “Information mythology: the world of/as information”, in Bud-

Frierman, L. (ed.), Information Acumen, Routledge, London, pp. 231-247.

Campbell-Kelly, M. (1994), “The Railway Clearing House and Victorian data processing”, in Bud-Frierman, L. (ed.), Information acumen, Routledge, London, pp. $51-74$

Companies House (1888), 25755 Mitchells \& Butlers, F, vol 1: 25 January 1888, Agreement for sale between Henry Mitchell and Herbert Bainbridge to Henry Mitchell \& Co of Cape Brewery, Companies House, London.

Companies House (1920), 25755, vol 12, shareholder return, 26 August

Crossick, G. (1977), The lower middle class in Britain, Croom Helm, London.

Galbraith, J (1991), “Strategy and organization planning”, in Mintzberg, H. and Quinn, J., (eds) The strategy process: concepts, contexts, cases, Prentice Hall, New Jersey, pp. 315-324. 
Gourvish, T. R , and Wilson, R. G. (1994), The British brewing industry 1830-1980, Cambridge University Press, Cambridge.

Gutzke, D. (1984), “The social status of landed brewers in Britain since 1840”, Histoire Sociale/Social History, 17, pp. 93-113.

Gutzke, D. (1989), Protecting the pub: brewers and publicans against temperance, Boydell Press, Woodbridge, Suffolk:

Harrison, B. (1994), Drink and the Victorians. The Temperance Question in England 1815-1872, Keele University Press, Keele.

Hawkins, K. (1978), A history of Bass Charrington, Oxford University Press, Oxford. Hoggart, R. (1971), The uses of literacy: aspects of working-class life, with special reference to publications and entertainments, Chatto and Windus, London.

Hyde, P. (1974), The occupational role of publican. Unpublished MPhil, University of Kent .

Jennings, P. (1995), The public house in Bradford, 1770-1970, Keele University Press, Keele.

Levenstein, M. (1998), Accounting for growth. information systems and the creation of the large corporation, Stanford University Press, Stanford.

M\&B (1898), BBM 95.2595.01, Managing Directors minute book 1888-1908, 1898 entry. Papers held at the Bass Museum, Burton on Trent.

M\&B (1903), BBM 95.2595.02, Managing Directors minute book 1903-1904, 28 July.

M\&B (1904a), BBM 95.2595.02, Managing Directors minute book 1903-1904, 1 February.

M\&B (1904b), BBM 95.2595.02, Managing Directors minute book 1903-1904, 22 February. 
M\&B (1905a), BBM 95.2595.01, Managing Directors minute book 1888-1908, 17 April.

M\&B (1905b), BBM 95.2595.01, Managing Directors minute book 1888-1908, 25 September.

M\&B (1905c), BBM 95.2595.01, Managing Directors minute book 1888-1908, 16 October.

M\&B (1905d), BBM 95.2595.01, Managing Directors minute book 1888-1908, 20 November.

M\&B (1906a), BBM 95.2595.01, Managing Directors minute book 1888-1908, 8 January.

M\&B (1906b), BBM 95.2595.01, Managing Directors minute book 1888-1908, 16 July.

M\&B (1906c), BBM 95.2595.01, Managing Directors minute book 1888-1908, 17 September.

M\&B (1906d), BBM 95.2595.01, Managing Directors minute book 1888-1908, 15 October.

M\&B (1907), BBM 95.2595.01, Managing Directors minute book 1888-1908, 15 July.

M\&B (1908a), BBM 95.2595.01, Managing Directors minute book 1888-1908, 10 February.

M\&B (1908b), BBM 95.2595.01, Managing Directors minute book 1888-1908, 23 November.

M\&B (1913), BBM 95.3099.01, Summary of Managed Houses Cash Books no 2 1913-1926. 
M\&B (1909), BBM 95.2595.03, Managing Directors minute book 1908-1910, 18 January.

M\&B (1935), BBM 95.2445.01, Schedule of Properties, Beer on-licences no 5.

MacKenzie, D. A. (1981), Statistics in Britain 1865-1930: the social construction of scientific knowledge, Edinburgh University Press, Edinburgh.

Mason, J. (1982), “Accounting records and business history”, Business History, 24, pp. 293-99.

Mass Observation (1970), The pub and the people, Seven Dials Press, London.

Mitchells \& Butlers (1929), Fifty years of brewing 1879-1929, Mitchells \& Butlers, Birmingham.

Moynihan, P. (1986), “Walker’s Ales”, Journal of the Brewing History Society”, 47, pp. 9-16.

Mutch, A. (1999), "From landlord to manager: change in beer retailing 1890-1980”, Paper presented to the Association of Business Historians Conference, September, South Bank University.

Peel (1897a), Royal Commission on the Licensing Laws. (The Peel Commission).. Minutes of Evidence Vol. 1, C8356, XXXIV.

Peel (1897b), Royal Commission on the Licensing Laws. (The Peel Commission).. Minutes of Evidence Vol. 2, C8523, XXXV.

Peel (1898a), Royal Commission on Licensing Laws. Minutes of Evidence, Vol 3 c8693, XXXV1.

Peel (1898b), Royal Commission on Licensing Laws. Statistics c8696, XXXVII. Shipstones (1909), DD/SH/9/6, Contract between F. Cookson and J. Shipstone and Sons, 15.4.1909, Nottinghamshire Archives. 
Walkers (1896), Walkers Warrington Ales, Peter Walker and Sons , Warrington, 1896 in Warrington Central Library, W52651.

White, J. (1986), The worst street in North London: Campbell Bunk, Islington, between the wars, Routledge, London.

Yates, J. (1989), Control through communication: the rise of system in American management, John Hopkins University Press, Baltimore. 